\title{
PELATIHAN VIRTUAL PENGGUNAAN APLIKASI MOBILE LEARNING BERBASIS E-LEARNING BAGI MAHASISWA PRODI PBA UNIVERSITAS MUHAMMADIYAH MATARAM
}

\author{
Nasarudin, Husnan \\ Universitas muhammadiyah mataram \\ nasarmtdn@gmail.com,Husnanin@yahoo.co.id
}

\begin{abstract}
Abstrak
Tujuan pelaksanan kegiatan ini adalah memberikan pelatihan virtual penggunaan aplikasi mobile learnig berbasis e-learning mahasiswa program studi pendidikan bahasa Arab Universitas Muhammadiyah Mataram. Hasil kegiatan ini yairu, bahwa dalam pelaksanaannya menempuh dua tahap yaitu tahap micropraktik dan tahap realpraktik. Tahap micropraktik diaplikasikan dengan memberikan pelatihan melalui proses pembelajaran online yang menggunakan aplikasi mobile learning seperti zoom meting, whatsapp, telegram, facebook. Sedangkan tahap pelatihan realpraktik diaplikasikan dengan melakukan pelatihan virtual via zoom meting dengan menyikan materi aplication mobile learning yaitu: zoom, google meet, google classroom, edmodo, edlink, webex, schology, dan whatsapp.

Kata kunci: Belajar daring, aplikasi, mobile learning.
\end{abstract}

\begin{abstract}
The purpose of implementing this activity is to provide virtual training on the use of e-learning mobile learning applications for students of the Arabic language education study program, Muhammadiyah Mataram University. The result of this activity is that the implementation takes two stages, namely the micropractic stage and the realpractice stage. The micropractic stage is applied by providing training through an online learning process using mobile learning applications such as zoom meting, whatsapp, telegram, facebook. While the real-practice training stage is applied by conducting virtual training via zoom meting by providing mobile learning application materials, namely: zoom, google meet, google classroom, edmodo, edlink, webex, schology, and whatsapp.
\end{abstract}

Keywords: Elearning, application, mobile learning.

\section{PENDAHULUAN}

Pada awal tahun 2020 dunia kejutkan oleh munculnya wabah virus corona yang berasal dari Wuhan China dengan nama Covid 19 yang telah menyerang 216 negara dan teritorial di dunia, tercatat 14.422.468 orang sudah terpapar wabah ini dengan angka kematian sebesar 603.823 orang, dengan sebaran tertinggi pada lima negara yaitu Amerika Serikat, Berazil, India, Rusia dan Afrika Selatan. Dan adapun Cina sebagai Negara asal mula covid 19 berada pada urutan ke-26, satu tingkat di bawah Indonesia pada urutan yang ke-25.

Indonesia merupakan salah satu negara menghadapi pandemi covid 19 pada bulan Juli 2020 dengan jumlah terinfeksi berjumlah 84.882 orang dengan korban meninggal dunia sebanyak 4.016 orang, yang telah menyebar di 34 provinsi dengan Jatim sebagai daerah tertinggi dan NTT sebagai daerah terendah. Adapun NTB pada urutan ke-12. Di NTB ada 1725 orang yang telah terkonvirmasi positif dengan rincian dirawat 534 (30.96\%), sembuh: 1097 (63.59\%) dan meninggal: 94 (5.45\%).

Hal ini telah banyak mempengaruhi bidang kehidupan masyarakat, di mana masyarakat harus mengubah pola hidup dengan mengikuti protokol kesehatan dalam upaya pencegahan covid 19, antara lain: menjaga kebersihan tangan, tidak menyentuh wajah, menetapkan etika batuk dan bersin, mengenakan masker, menjaga jarak, dan isolasi mandiri.

Menjelang estimasi waktu penyeberan selesai covid 19 pada titik jenuh yaitu bulan Mei 2020 Pemerintah menerapkan kehidupan kenormalan baru (new normal). New normal adalah langkah percepatan penanganan COVID-19 dalam bidang kesehatan, sosial, dan 
ekonomi. Skenario new normal dijalankan dengan mempertimbangkan kesiapan daerah dan hasil riset epidemiologis di wilayah terkait.

Kehidupan kenormalan baru meminta masyarakat untuk mampu hidup terbiasa dengan covid 19. Manusia punya sejarah dan pengalaman hidup berdampingan dengan mikroba seperti virus influenza, HIV, dan demam berdarah, yang perlu dilakukan adalah mengenali virus tersebut untuk bisa mencegah penularannya.

Dampak covid 19 telah sangat dirasakan masyaakat di semua bidang seperti bidang pendidikan. Lembaga pendidikan baik sekolah dan perguruan tinggi telah banyak menyelenggarakan peroses kegiatan belajar mengajar via daring secara online (e-learning) dengan menggunakan program yang bisa diaplikasikan menggunakan destop maupun mobile.

E-learning adalah suatu sistem pembelajaran yang menggunakan teknologi berbasis internet tanpa berinteraksi langsung dalam proses pembelajaran, dengan membutuhkan infrastruktur seperti: jaringan internet lektop atau handphone. Sistem dan aplikasi e-learning yang sering disebut dengan Learning Management System (LMS), yang merupakan sistem perangkat lunak yang mem-virtualisasi proses belajar mengajar konvensional untuk administrasi, dokumentasi, laporan suatu program pelatihan, ruangan kelas dan peristiwa online, program e-learning, dan konten pelatihan, misalnya, segala fitur yang berhubungan dengan manajemen proses belajar mengajar seperti bagaimana manajemen kelas, pembuatan materi atau konten, forum diskusi, dan sistem penilaian.

Menurut Clark Quinn mobile learnig is The intersection of mobile computing and elearning: accessible resources wherever you are, strong search capabilities, rich interaction, powerful support for effective learning, and performance-based assessment. ELearning independent of location in time or spac. Artinya bahwa titik temu komputasi mobile dan e-learning: sumber daya yang dapat diakses di mana pun Anda berada, kemampuan pencarian yang kuat, interaksi yang kaya, dukungan yang kuat untuk pembelajaran yang efektif, dan penilaian berbasis kinerja. ELearning terlepas dari lokasi dalam waktu atau ruang.

Mobile web ini merupakan sebuah situs web yang biasanya Anda akses melalui komputer atau laptop, namun situs web tersebut didesain untuk dibuka pada browser perangkat yang lebih kecil seperti smartphone atau tablet. mobile app adalah aplikasi mobile yang memang dirancang khusus untuk di-Install di perangkat smartphone atau tablet.

Aplikasi adalah suatu perangkat lunak (software) atau program komputer yang beroperasi pada sistem tertentu yang diciptakan dan dikembangkan untuk melakukan perintah tertentu. Kriteria aplikasi mobile learning yang efektif dalam electronik learning, antara lain: berinterkasi via video, berinteraksi via chat, berinterkasi dengan presentasi, dapat mengirim dan mnerima file, dan mempunyai tool absensi. Diantara program-program yang dapat digunakan dalam e-learning antara lain: zoom, edlink, google clasrrom (hangout), google meet, cisco webex, edmodo, schoology, whatsapp beta messenger, dll.

Salah satu perguruan tinggi yang akan menerapkan e-learning adalah Universitas Muhammadiyah Mataram (UMMAT), dalam pembelajaran semsster genap tahun akademik 2019/2020 mulai bulan April s.d September 2020. Dan baru pertama kali UMMAT menyelenggerakan perkuliahan elearning yang mungkin banyak mengalami kendalakendala seperti skill SDM dalam penguasaan teknis aplikasi elearning, infrastruktur elearning, dan model pembelajaran.

Dari aspek SDM, banyak dosen yang belom bisa dan belom berpengalaman dalam pembelajaran elearning, apalagi mahasiswanya. Dan dari aspek infrastruktur elearning membutuhkan lektop model terbaru yang harus suport dengan browser terupdate supaya sebuah aplikasi elearning bisa dioperasionalkan, dan juga membutuhkan jaringan internet 
yang kuat dan lancar. Dan dari model pembelajaran dalam proses pembelajaran mulai dari absen mahasiswa, penampilan materi, metode pembelajaran, sistem evaluasi akan banyak menemukan tantangan dan hambatan.

Hambatan-hambatan tersebut akan banyak dialami pada tingkat prodi seperti prodi pendidikan Bahasa Arab, terutama dari unsur mahasiswa. Mahasiswa prodi PBA banyak mengalami keterbatasan berkaitan dengan teknologi seperti belum pernah menggunakan aplikasi webinar dalam prose pembelajaran.

Pada semester genap tahun akademik 2019/2020 Universitas Muhammadiyah Mataram tidak menggunakan aplikasi tertentu dalam kuliah online karena berbagai kendala meskipun sudah memiliki aplikasi atau program kuliah online sendiri. Dan dalam pelaksanaan perkuliah online teknis perkuliahan diserahkan kepada dosen, yang menggunakan aplikasi yang beragam sesuai dengan skill masing-masing dosen. Dan adapun mahasiswa mengikuti perkuliahan online sesuai dengan keadaan dosen meskipun atas kesepakatan bersama antara dosen dan mahasiswa. Dan mahasiswa harus punya variasi skill tersendiri dalam menggunakan aplikasi mobile learning untuk ikut kuliah online tersebut.

Berdasarkan hal tersebut tim melakukan pelatihan Penggunaan Aplikasi Mobile Learning Berbasis E-Learning Bagi Mahasiswa Prodi PBA Universitas Muhammadiyah Mataram. Dengan kegiatan ini mahasiswa prodi PBA diharapkan mampu mengoperasionalkan sebuah aplikasi elearning seperti: zoom, google classroom, dll. sehingga kegiatan pembelajaran di prodi PBA dapat berjalan lancar.

\section{METODE}

Dalam melaksankan kegiatan pengabdian ini yang menyasar mahasiswa yang ada di prodi Pendidikan Bahasa Arab Fakultas Agama Islam Universitas Muhammadiyah Mataram menggunakan metode pelatihan dan praktik online, Sebgai inplementas work from home $(W F H)$ yaitu bekerja dari rumah maka dalam kuliah online dosen mengajar dari rumah dan mahasiswa belajar dari rumah. Berkaitan dengan pelaksanaan pelatihan penggunaan aplikasi $\mathrm{m}$-learning berbasis e-learning kepada mahasiswa PBA maka pelaksanaan dengan online via zoom meting.

\section{HASIL DAN PEMBAHASAN}

Pelaksanaan kegiatan pengabdian ini yang bertemakan pelatihan penggunaan aplikasi mobile learning berbasis e-learning terintegrasi dengan perkuliahan online semester genap tahun akademik 2019/2020. Maka pelatihan ini ada dua model yaitu model, yaitu model mikropraktik sebagai partisipan dan model realpraktik sebagai host.

\section{Model Mikropraktik}

Model mikropraktik diaktualisasikan dalam sebuah pelaksanaan perkuliah sesuai jadwal kuliah matakuliah yang diajarkan oleh tim pelaksana. Pelaksanaan ini dengan memperhatikan keadaan dosen dan mahasiswa dan spesifikasi dan karakter matakuliah, sehingga dengan tepat menentukan jenis aplikasi m-learning yang digunakan. Matakuliah yang bersifat kognitifisme menggunakan yang berbeda dengan matakuliah yang bersifat pskimotorikisme.

Setelah mempertimbangkan hal tersebut langkah selanjutnya adalah memberikan arahan kepada mahasiswa tentang penggunaan aplikasi m-learning yang akan digunakan namun sebatas informasi penggunaan aplikasi tersebut untuk bias mengikuti perkuliahan.

Untuk menefektifkan penyampaian informasi tersebut dibuatlah sebuah group whatsapp yang dijadikan sebagai pusat informasi penggunaan aplikasi mobile learning (AML). Segala macam informasi baik dari pihak dosen dan mahasiswa tertuang dalam WAG ini. 
Dan telah disepakati bahwa aplikasi yang pertama digunakan adalah aplikasi zoom meting free yang punya limit waktu 40 menit. Sebelum pelaksanaan perkuliahan zoom meeting dosen memberikan informasi teknik penggunaan zoom meeting, mulai dari cara penginstallan, membuka aplikasi zoom saat ikut perkuliahan, dan cara berinterkasi presentator dan audiens dalam diskusi perkuliahan, dan alternative lain ketika mahasiswa menghadapi sinyal lemot.

Berikut tahapan-tahapan micropraktik. Pertama, penggunaan aplikasi zoom meeting, yaitu dimulai dengan pengistalan aplikasi zoom lewat playstore bagi pengguna android dan membuka link http://www.zoom.us bagi pengguna desktop, dilanjutkan dengan pembuatan akun ID zoom dengan menyiapkan email aktif. Kemudian dosen memberikan ID meeting atau link meeting untuk setiap pertemuan untuk masing-masing matakuliah. Mahasiswa mulai menggunakan zoom dalam perkuliahan dengan menegetik ID meeting dan menggunakan nama sesuai nama di daftar hadir sekaligus absensi perkuliahan dengan mengoffkan video sebagai antisipasi pemborosan kuota, dan diminta meng-on-kan video untuk kebutuhan verefikasi kehadiran online.

Dalam berinteraksi via zoom, mahasiswa sebagai penyaji diskusi menyiapkan file .ppt untuk ditampilkan dalam screen zoom melalui host pada 40 menit zoom pertama yang dipandu oleh moderator, dan host meng-unmute audio para peserta. Adapun peserta bias bertanya dengan menggunakan fitur risehend sebagai pemberi tanda bertanya langsung kepada pemateri atau chat untuk memberi pertanyaan secara tertulis.

Kedua, penggunaan whatsapp beta messenger, dimulai dengan pengintalan aplikasi whatsap beta di link http://www.apkmirror.com karena tidak tersedia di playstore, kemudian melakukan aktivasi menggunakan nomor selurer, lalu membuka link yang dibuat dosen melalui forum whatsapp dan link dibagikan ke semua mahasiswa dan mereka dapat terkoneksi dengan browser chrome atau aplikasi messenger, dan dapat melakukan interkasi pembelajaran dalam sebuah forum messenger. Dan untuk pengoftimalan peroses interkasi ini mahasiswa dibuatkan code QR untuk dishere setiap perkuliahan sebagai data absensi.

Ketiga, telegram. Apliaksi telegram dapat digunakan sebagai alat perkuliahan online tapi tidak bisa dalam forum video. Telegram sebagai alternative perkuliahan untuk hemat kuota. Aplikasi instagram dapat di download di playstore dengan menyiapkan nomor HP untuk pembuatan akun dapat mengunakan username tanpa memunculkan nomor HP. Dosen membuat group yang link group dishere kepada mahasiswa sehingga mahasiswa bisa bergabung ke group. Intraksi perkuliahan dapat dilakukan dengan chat, pesan suara dan pengiriman file. Dan untuk kebutuhan apsensi perkuliahan ada fitur polling yang dapat digunakan sebagai absensi mahasiswa.

Keempat, facebook. Aplikasi facebook sebuah aplikasi familier di kalangan mahasiswa, hampir semua mahasiswa sudah memiliki mahasiswa sehingga dengan mudah digunakan untuk perkuliahan daring, tinggaldiberikan polesan lagi sehingga lebih dapat diofitmalkan dalam pembelajaran. Facebook digunakan untuk live video untuk matakuliah microteaching. Sedangkan untuk perangkat pembelajaran seperti silabus dan RPP maupun absensi siswa dapat dilampirkan di laman facebook dengan mengintegrasikan dengan google drive. Caranya dengan mengopload file di drive dan berbagi link. Dan link tersebut dibagikan di laman facebook sehingga fila bisa diunduh orang lain dan supaya direct download, link dapat dikombinasikan dengan link https://docs.google.com/uc?export=download\&id=ID dan link link dari shere google drive yang sudah dibagikan sebelumnya, seperti https://drive.google.com/file/d/1W91WPYGvx1e0XdMtDQhLjEsy-

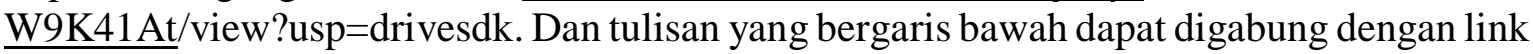
warna biru sebelumnya menjadi https://docs.google.com/uc?export=download\&id=1W91WPYGvx1e0XdMtDQhLjEsy- 
W9K41 At. Jika sudah dibuat seperti ini maka tinggal di copy paste di laman facebook, dan file di drive diunduh orang lain.

Adapun absensi di facebook menggunakan poling group atau status group yang dibuat oleh dosen, sedangkan mahasiswa tinggal mengisi poling atau mengomentari postingan tersebut dengan mengetik kata hadir.

Model micropraktik ini hanya melatih kepada mahasiswa agar mempunyai wawasan yang memadai sebagai joiner atau partisipan saja, namun dapat menjadi bekal dalam mengikuti pelatihan realpraktik untuk menjadi admin dan host.

\section{Model Realpraktik}

Pelatihan model realpraktik merupakan pelatihan dengan memberikan tutorial lamgsung kepada mahasiswa tentang cara menggunakan aplikasi baik sebagai host maupun partisipan dengan membahas secara langsung hakekat aplikasi tersebut baik secara teoritis maupun praktis. pelatihan ini menggunakan media zoom berbayar sehingga mahasiswa mengetahui fitur-fitur aplikasi tersebut dengan melibatkan mahasiswa sebagai co-host.

Berbeda dengan pelatihan micropraktik yang menjadikan aplikasi sebagai sarana prasarana pembelajaran, dimana pelatihan relapraktik ini menjadikan aplikasi sebagai tujuan supaya bisa digunakan dan memenej sendiri sebagaimana fungsi host sebuah aplikasi. Pelatihan ini dapat melibatkan mahasiswa untuk tahu betul tentang penggunaan sebuah aplikasi mobile learning yang dapat digunakan dalam pembemlajaran online.

Adapun proses pelaksanaannya dimulai dengan tahapan pendaftaran melalui form docs google yang dibuat tanggal 2 Juli 2020 dan dapat diakses di link http://www.klip.ai/nasarudin, karena kegiatan ini terbuka untuk umum yang tertarik mengikuti pelatihan virtual ini. Kuota peserta zoom yang dipersiapkan untuk 500 peserta (partisipan), dan sampai tanggal 23 Juli 2020 ada 58 orang yang sudah mendaftarkan dirinya melalui link tersebut. Semua para peserta tersebut dikirimkan informasi tentang pelaksanaan tersebut satu hari menjelang kegiatan pelatihan melalui email para peserta. Pengiriman via email ini dilakukan secara serentak menggunakan aplikasi FormMule - Email Marge Utility, dengan bentuk sebagai berikut.

Adapun informasi yang disampaikan adalah yang berkaitan dengan link zoom yang $\begin{array}{lllll}\text { akan diikuti } \quad \text { yaitu: } & \text { Moom }\end{array}$ https://zoom.us/j/97799744811?pwd=T1IrU2RuQk11cENzaHVXN1huVDVUdz09.

Meeting ID: 97799744811 Password: 399018.

Penyampaian materi dalam latihan ini disajikan oleh penyaji secara online dengan menggunakan metode demontrasi baik menggunakan desktop maupun android. Dengan menggunakan simulasi ini dapat memberikan pengetahuan yang nyata bagaimana mengoperasionalkan sebuah aplikasi yang dapat difungsikan sebagai pembelajaran daring, karena saat ini mahasiswa dituntut untuk tidak sekedar menjadi partisipan tapi juga sebagai host atau admin sebuah aplikasi, mengingat saat ini hampir semua sekolah menerapkan pembelajaran daring. Bagi mahasiswa yang ada paa semester enam harus menempuh program praktik lapangan untuk mengajar di sekolah madrasah, selain itu juga untuk jangka panjang hasil pelatihan ini dapat dijadikan bekal melakukan jarak jauh.

Acara pelatihan ini dilaksanakan pada tanggal 26 Juli 2020 mulai pada jam 09.00 wita dengan susunan acara sebagai berikut.
a. Pembukaan
b. Sambutan Dekan FAI
c. Penyampaian materi
d. penutup

Adapun materi-materi yang disampaikan sebagai berikut dengan materi lengkap dapat diakses di link https://bit.ly/MateriNasarudin.

1) Zoom Meet https://zoom.us 
2) Google Meet https://meet.google.com

3) Google Kelas https://classroom.google.com

4) EdLink https://edlink.id

5) Edmodo https://www.edmodo.com

6) Schoology https://www.schoology.com

7) Whatapp Beta Massenger https://bit.ly/WhatappBeta

8) Webex meeting https://www.webex.com

Kegiatan ini tidak hanya bisa diikuti via zoom meeting tapi juga bisa diikuti via youtube dengan link https://bit.ly/YoutubePelatihan secara livestreaming. Dan para peserta dapat memilih media tersebut yang dianggap mudah dan memungkinkan untuk mengikuti acara pelatihan ini.

Kegiatan ini menyiapkan e-sertifikat untuk narasumber dan para peserta yang mengikuti kegiatan ini dengan mengisi daftar hadir via form docs google menjelang 30 menit berakhirnya acara kegiatan. Dan e-sertifikat langsung diterima di email masing-masing setelah mengisi daftar hadir tersebut, karena e-sertifikat ini telah dipsersiapkan melalui aplikasi goole slide, google spreadsheet dan autocrat. Para peserta pelatihan dapat melakukan daftar hadir online di link https://bit.ly/Absen26Juli2020 .Berikut tampilan esertifikat di google slide.

Dalam kegiatan pengabdian ini dengan tema pelatihan virtual penggunaan aplikasi mobile learnig berbasis e-learning, prodi pendidikan bahasa Arab sebagai mitra pengabdian memberikan andil dan sumbangsih yang besar dan signifikan, di mana mitra ini dalam tahap mikropraktik memberikan kewenangan kepada tim pelaksana kegiatan untuk menggunakan aplikasi mobile learnig yang mungkin untuk digunakan sehingga dengan mudah para tim pelaksana untuk mengatur setingan kegiatan pelatihan ini.

Demikian juga pada tahap realpraktik mitra dengan semangat melakukan sosialisasi kepada mahasiswa melalui group WA sehingga informasi tentang pelaksanaan pelatihan ini sampai ke telingan mahasiswa sehingga $75 \%$ dari mereka ikut dalam pelatihan ini. Dan pejabat dekanat bersedia memberikan sambutan dalam kegiatan pleatihan virtual yang membuat kegiatan pelatihan ini bertambah meriah.

Adapun peranan lain dari mitra dalam kegiatan ini adalah mengkodinir mahasiswa, menyiapkan jaringan wifi, menyiapkan lokasi kegiatan, dan membantu tim dalam meksimalkan kegiatan. Semua dukungan total mitra tesebut mampu membantu tim pelaksana pengabdian memberikan solusi dari permasalahan yang terjadi, yaitu dengan memberikan pelatihan penggunaan aplikasi mobile learning berbasis e-learning bagi mahasiswa Prodi PBA Universitas Muhammadiyah Mataram, dari tahapan rencana kegiatan mulai dari pemberian tutorial penggunaan aplikasi zoom cs, praktik menggunakan aplikasi zoom cs, dan simulasi pembelajaran menggunakan aplikasi zoom cs.

Berdasarkan tahapan kegiatan pelaksanaan pelatihan ini tim pelaksana menemukan hal-hal yang perlu untuk diperhatikan dan ditindaklanjuti, antara lain sebagai berikut.

1. Pelatihan seperti ini harus berkala diselenggarakan

2. Terdapat potensi yang handal dari para peserta pelatihan untuk dibina lebih lanjut oleh lembaga mulai dari lembaga kemahasiswaan seperti HMJ dan BEMF dan lembaga kampus dari prodi, fakultas dan universitas.

3. Diperlukan kegiatan pelatihan langsung sehingga apa yang didemontrasikan dapat dipahami dan diresapi dengan cepat dan mudah.

Jadwal kegiatan pelatihan virtual penggunaan aplikasi mobile learnig berbasis elearning sebagaimana dalam tabel berikut ini. 
Tabel 1. Jadwal kegiatan pelatihan virtual penggunaan aplikasi mobile learnig berbasis elearning

\begin{tabular}{|c|c|c|c|c|c|c|c|c|c|}
\hline \multirow[t]{2}{*}{ No. } & \multirow[t]{2}{*}{ Kegiatan } & \multicolumn{4}{|c|}{ Juni } & \multicolumn{4}{|c|}{ Juli } \\
\hline & & 1 & 2 & 3 & 4 & 1 & 2 & 3 & 4 \\
\hline 1. & Perencanaan kegiatan pelatihan dengan mitra & $\mathrm{x}$ & & & & & & & \\
\hline 2. & $\begin{array}{l}\text { Pelaksanaan kegiatan Pelatihan virtual tahap } \\
\text { micropraktik }\end{array}$ & & $\mathrm{X}$ & $\mathrm{x}$ & $\mathrm{x}$ & $\mathrm{x}$ & $\mathrm{x}$ & & \\
\hline 3. & $\begin{array}{l}\text { Konsolidasi dengan mitra dengan membahas } \\
\text { kendala dalam melaksanakan pelatihan }\end{array}$ & & & & & & & $\mathrm{x}$ & \\
\hline 4. & $\begin{array}{l}\text { Pelaksanaan kegiatan Pelatihan virtual tahap } \\
\text { realpraktik }\end{array}$ & & & & & & & & $\mathrm{x}$ \\
\hline
\end{tabular}

\section{KESIMPULAN}

Berdasarkan proses pelaksanan kegiatan pelatihan virtual penggunaan aplikasi mobile learnig berbasis e-learning dapat disimpulkan bahwa dalam pelaksanaannya menempuh dua tahap yaitu tahap micropraktik dan tahap realpraktik. Tahap micropraktik diaplikasikan dengan memberikan pelatihan melalui proses pembelajaran online yang menggunakan aplikasi mobile learning seperti zoom meting, whatsapp, telegram, facebook. Sedangkan tahap pelatihan realpraktik diaplikasikan dengan melakukan pelatihan virtual via zoom meting dengan menyikan materi AML yaitu: zoom, google meet, google classroom, edmodo, edlink, webex, schology, dan whatsapp.

\section{SARAN}

Berdasarkan proses pelaksanaan kegiatan pelatihan virtual penggunaan aplikasi mobile learnig berbasis e-learning dapat memberikan sumbangsih saran yaitu:

a. Perlu membuat perencanaan yang matang dengan mitra trutama kendala yang ter terduga sehingga sebuah kegiatan dapat berjalan optimal.

b. Perlu membangun komunikasi lebih intens antara pelaksana, mitra, dan subjek kegiatan pengabdian, sehingga dapat mengatasi segala macam hambatan dan rintangan saat kegiatan berlangsung.

EdLink https://edlink.id

\section{DAFTAR PUSTAKA}

Edmodo https://www.edmodo.com

Google Kelas https://classroom.google.com

Google Meet https://meet.google.com

https://corona.ntbprov.go.id

https://www.covid19.go.id

https://www.gurupendidikan.co.id/pengertian-e-learning/

https://www.worldometers.info/coronavirus/ . 
Seminar Nasional Penelitian dan Pengabdian kepada Masyarakat Universitas Sang Bumi Ruwa Jurai Tahun 2020

https://zoom.us

Schoology https://www.schoology.com

Webex meeting https://www.webex.com

Whatapp Beta Massenger https://bit.ly/WhatappBeta 